\title{
Spatial Polarization of National Economy: Current State and Development Priorities
}

\author{
Rakhaev Kh.M. \\ Department of Management \\ Kabardin-Balkar State Agrarian University \\ Nalchik, Russia \\ $\underline{\text { 3bizengin@mail.ru }}$ \\ Sozaeva T.Kh. \\ Kabardino-Balkarian State Agrarian University, \\ Nalchik, Russia \\ sozaytanzilya@yndex.ru
}

\author{
Sulumov S.Kh. \\ Human Resources Department \\ Chechen State University \\ Grozny, Russia \\ sbek@ rambler.ru
}

\begin{abstract}
Economy develops in space and time. The factor of special position has always had an impact on its dynamics since spatiality remains the most important feature of territories' development. In one case it is a positive influence, in another - a restraining effect on national economy development. The influence of space on the economic development of a territory is great. However, it is not completely clear how space affects the economic dynamics of the territory. Space in itself in economics is perceived as a place of resources or natural communications concentration. In other words, the space itself is perceived not as a space in general, but through certain geographical features of the territory. Thus, it is not the space per se that is evaluated, but some of its features on which various theoretical models of evaluating economic space are constructed, i.e. features of space as factors of economic development. Up to the present moment little attention has been given to the issue of polarization on national economy. It is understood as existing a spatial vector of development (or a gradient of territorial development). In this article it has been attempted to identify perspective directions of developing the national economy of the Russian Federation. In the research of spatial development of territory two vectors of its activeness have been detected: the first one - European and the second - Asian.
\end{abstract}

Keywords - spatial economy; polarization of national economy; development gradient; macroregion; European and Asian megaregions

\section{INTRODUCTION}

Space appears in various statuses: depending on the territory, geographical location, geographical, climatic and other features of "geographical space". The influence of space on the economic development of a territory is great. However, it is not completely clear how space affects the economic dynamics of the territory. Space in itself in economics is perceived as a place of concentration of resources or natural communications. In other words, the space itself is perceived not as a space in general, but through certain geographical features of the territory. Thus, it is not the space per se that is evaluated, but some of its features on which various theoretical models of evaluating economic space are constructed, i.e. features of space as factors of economic development.

\section{LITERATURE REVIEW}

Such studies are conducted in Europe since ancient times, other regions (Egypt, the Middle East, China and other parts of the world) also have their own "regional concepts and views" on the nature of space in the economy. Particular activity in this area took place in the 18th and 19th centuries in Europe, where the foundations of future spatial studies were set not fragmentarily but conceptually. In this connection, the works of J. Tünen [19], V. Launhardt[9], A. Weber[6], W. Aizard[1], J. Budwill[4], A. Lyosh[10], F. Perru[13] should be pointed out, the authors who for decades determined the main vector of scientific research in the field of spatial economics or territorial development. In the XX century, this direction received a large-scale development, national schools were formed with clear national research programs. In Europe there were such national schools as German, French, British, Scandinavian (Swedish) and Russian. This makeup of scientific research is not only explained subjectively but also has its objective reasons that form the space of a specific national economy (national territory). The fact is that the economic space, unlike the geographical one, is a set of national institutions that express a specific way of space economic development by people. In this regard, not only its depth but also the landscape are in many respects different depending not on latitude, longitude and other geographical parameters but on history, mentality and ethical characteristics. It is important to note that geographical features are involved in the formation of the economic space but, at a certain stage, their influence is eliminated by other factors and conditions (technologies, institutions, etc.). In the 
Thus, by economic space we understand the combination development of the theoretical and methodological foundations of spatial economics also took part Russian scientists: A. Smith[16], P. Krugman[8], V. Leontiev[12], A. Granberg[7], V.Leksin[11], A.Shvetsov[11] and others. They formed the basis of the future Russian school of spatial economy.

However, until the twentieth century, in most works, space is perceived as an endogenous trait. An important leap in this regard was made by A.Lyosh[10] in 1940 by publishing his book "The Spatial Organization of the Economy". The work of A.Lyosh was in many ways revolutionary. However, F. Braudel[2] had the most revolutionary influence on the scientific study of space in the economy with his theory of "worlds-economies". Apparently, for the first time in world practice (economic science), space is clearly seen not from the point of view of habitual geographical features but from the point of view of communications in the form of transport routes (auto, railway, sea roads, stations, etc.). On the other hand, the economy is not viewed as the production of goods and services, but as a kind of integrity. It was a methodological innovation. F. Braudel [3] managed to bring the economy and economic development out of the traditional system of elements and factors, denoting for the first time an economic unity as the only reality.

A distinctive feature of the current stage of research in the framework of spatial economics development is the wide use of models and methods for quantifying the characteristics of the economy individual sectors functioning, the dynamics of the structure and volumes of interregional exchange, the formation of economic agglomerations and other related issues.

To date, two points of view have emerged on the phenomenon of space in economic dynamics and economic development. One recognizes space as a growth factor, the other - as a deterrent. Both points of view have in their proof a certain set of logical positions and empirical facts. However, some inaccuracies admitted in the approbation can be traced. First, space cannot be considered abstract. Any space from economic and social points of view has its own characteristics, which either promote economic activities or they do not. Secondly, space should be correlated with the population mass, area of the territory and other indicators, i.e. the indicator of favour should be identified. Otherwise, nothing will happen in the assessment of its influence. In this regard, along with the "population density" of the space, a number of other indicators can be used as well (GDP/GRP per unit of space/territory, etc.). These indicators, expressing the degree of differentiation of space, are important from the point of view of space efficiency[17]. Although they are relative, i.e. they change from epoch to epoch and do not act as something static. The reason for such an attitude to space/territory is that, depending on the "value" of a particular resource, the value of the space itself also changes. Thus, in the period when coal (and, in general, solid hydrocarbons) acted as the most important resource, the territories/spaces in which these resources (raw materials) are located had value. But with the discovery of the value of oil and gas, the value of the former fell, while the value of the latter rose. of geographical, climatic, resource, production, communication and other factors and conditions concentrated on a certain territory, thereby distinguishing the territory as an area of space with a certain production and economic potential and carrying out its production and economic specialization. The latter can be considered as "poles" in space. Each such "pole" of space has its own direction or vector of development, which we consider as the polarization of space. In this case all the "poles" interact with each other, defining a certain common vector or gradient of space. We proceed from the assumption that the spatial development of the national economy is determined by the gradient. This article is devoted to the assessment of that trait.

\section{RESEARCH MethodOLOGY}

The entire territory of the Russian Federation (RF) was divided into two mega-regions: European and Asian. The European mega-region consists of the following macroregions (federal districts): Central Federal District (CFD), North-West Federal District (NWFD), North Caucasian Federal District (NCFD), Southern Federal District (SFD) and Volga Federal District (VFD). The Asian mega-region comprised the Urals Federal District (UFD), the Siberian Federal District (SFD), and the Far Eastern Federal District (FEFD). The comparison was carried out according to the same number of parameters for four periods: 2005, 2010, 2014 and 2015. The methodological foundation is based on the calculation of the macroregion's share in a particular parameter (indicator). Then, by summing up the share of the regions of one megaregion the overall or aggregated index of the mega-region was calculated and then compared by years and between each other. In the course of the comparison a deviation was calculated, which revealed that the overall or aggregated index of economic growth for the European mega-region for the period from 2005 to 2015 had changed in a positive direction. First, its overall value increased by $101.03 \%$, while that of the Asian mega-region fell to $94.35 \%$. Thus, the average value for the European mega-region turned out to be almost 1/3 higher than for the the Asian, and, moreover, it tended to increase due to the fact that it grows in the European mega-region, whereas it falls in the Asian mega-region [14]. Secondly, the value of the European index is more than two times higher than the Asian one. Thus, the level of the Asian region in the metric of the above index is only about $45 \%$ of the European value, i.e. the economic development index of the Asian mega-region is more than two times lower than the European one.

Thus, the above calculations indicate, firstly, an increase in the economic potential of the European mega-region as a result of its growth and a decrease in the dynamics in the Asian mega-region, and secondly, there is no question of any shift of the economic center in the eastern direction. On the contrary, the European mega-region is increasing its weight in the national economy.

The proposed method of calculating the economic center and changes in the economic space of the country, along with simplicity in the calculations, contains a number of shortcomings: 1) all industries and activities are equalized, but the "weight" of various industries in the growth of different 
territories turns out to be different; 2) there are no clear criteria for the differentiation of industries and territories and the "degree of significance" for the growth of the national economy. In this regard, it is necessary to determine the priority of the growth of the country's national economy, which should be laid as the basis for assessing the overall index of the territory development. First, the total territory index should not be calculated by "weight" (i.e., the specific weight of a particular industry products), but only by priority areas (i.e. take the specific weights of products from those industries and activities that are related to priority areas of the national economy). Secondly, it is necessary to carry out the adjustment of the shares (specific weights) to the priority factors to be calculated: a) based on the significance of the correlation coefficient between the products of the priority industry and the GRP, b) by growth rates.

It is important to note that priority should be understood as a preference in development. The latter can be estimated in terms of investments (direct and indirect, i.e., through the distribution of the population consumer spending). It cannot remain constant and changes from time to time. In addition, different regions have their own priorities based on the investment attractiveness of their regional economies. To calculate the priority, it is proposed to use the indicator of investment preference, which could be calculated as the share of investment in a particular industry in relation to the total investment [20].

\section{RESUlTS}

The obtained calculations show that the priorities in terms of investment attractiveness for the period from 2010 to 2015 in the whole of the Russian Federation almost did not change the main flow of investment was directed to three sectors: 1) transport and communications (over 20\% but with decreasing trends; in 2015, the share of investment in transport and communications decreased compared to 2010 by 5.3\%); 2) mining and mineral extraction (over $15 \%$, and there is a clear growth trend in 2015, the share of this segment increased by 3.4\% compared to 2010 and came close to the share of transport and communications, and without communications it exceeded transport); 3) manufacturing (about 15\% and with a slight upward trend - in 2015 compared to 2010, the share of this segment increased by $1.3 \%$. However, at the same time, it is less for $2 \%$ to $3 \%$ of the investment in mineral extraction and that preference is growing). The share of investment in agriculture also increased. As for other industries, for example, production and distribution of electricity, gas and water as well as construction, in the first segment there is a decrease in investment (-3.1\% from 2010 to 2015), and in the second, the value itself is low and there is also a decrease ($0,8 \%)[15]$.

However, investment preferences identified at the country level are not confirmed at the mega- and macro-regional levels (Fig.1). In particular, for the European mega-region, transport and communications account for the greatest investment preference, which is $2-3 \%$ higher than the nationwide ratio.

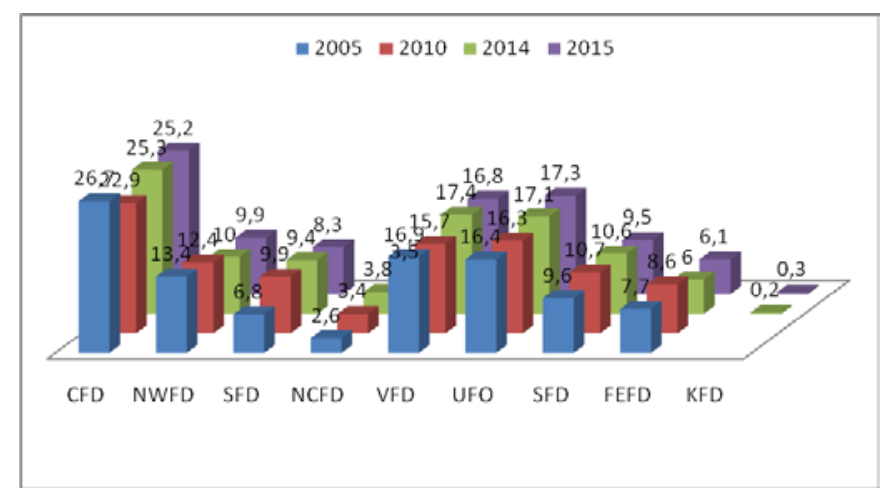

Fig. 1. Capital stock investment dynamics by RF federal districts, \% [15].

So, although transport is preferred, the share of communications is also growing at a higher rate than at the country level. In the second place, in contrast to country preferences, are manufacturing industries (their share in 2015 was $19.1 \%$ and this is almost $0.5 \%$ higher than in 2010, but lower than in 2014 by $2.5 \%$ ). In the third position are investments in the production and distribution of electricity, gas and water (about 10\%). Fourth-fifth place is shared by agriculture, wholesale and retail trade and the technical equipment service sector. The share of agriculture is relatively stable $-4.2 \%$. A large share of investments in the European mega-region accounts for real estate transactions, rent and provision of services, which generally repeats the countrywide feature.

As for the Asian mega-region, here the situation with investment preferences differs from the European mega-region and is closer to the country preferences. In it, the dominant segment in investment is investment in the extraction of minerals. The share is over 43\%. Moreover, if in 2010 this share was 35.3\% and in $201434.0 \%$, then in 2015 it was $43.2 \%$, i.e. there is a clear tendency for the investment attractiveness preference of this sector in the mega-region economy. As for the macro-regional aspect, the largest amount of investment in mining was observed in the UFD (over $50 \%$ and with a growing trend), in the second place is the FEFD (39.4\% in 2015, which is almost 20\% higher than in 2010). Thus, in the Asian mega-region, investment in mining represents an absolute investment preference. Within it, this preference is divided into Western (UFD) and Eastern or Pacific (FEFD). In the second place are investments in transport and communications, which account for $16.2 \%$ in 2015 and $24.6 \%$ in 2010. Furthermore, while the share of communications remains almost unchanged (about 2.5\%), the share of investment in transport decreases. In 2010, the share of transport accounted for $22.0 \%$, and in 2015 it is only $13.7 \%$, i.e. the reduction is by $8.3 \%$. The main decline occurred in the FEFD, where the share decreased from $43.9 \%$ in 2010 to $11.6 \%$ in 2015 , i.e. by $32.3 \%$. In third place is investment in the production and distribution of electricity, gas and water: $8.1 \%$ in 2015, which is less by $1.0 \%$ than in 2010 and less than in 2014 by $2.2 \%$. Within the mega-region, investment preference was given to this segment in the Far Eastern Federal District and the Siberian Federal District. The share of the investment attractiveness of manufacturing 
industries ranks fourth in the Asian mega-region with a share of $6.4 \%$ in 2015. It is lower than in 2014 and 2010 by almost $4 \%$, i.e. there is a decrease in the investment attractiveness of the manufacturing industries in this mega-region. The main part is observed in the UFD and the SFD, which have reduced their shares, whereas the FEFD has increased its shares in 2015 compared to 2010 and since 2014 it has decreased them by $0.7 \%$.

There is another criterion of priority, which is the growth dynamics, i.e. to evaluate priority by the growth rate of the industry or type of activity. So in this regard, three criteria should be indicated: a) when the growth rates for the industry turn out to be higher than the average for the national economy (i.e., higher than the growth rates for GRP or GDP), b) when the growth rates are equal to the average for the national economy, c) growth rates are lower than the national average.

These criteria allow us to rank industries by priority identifying in them: promising (priority) ones, current (existing) ones and past (or yesterday) ones. Now, on the basis of the proposals made, we will calculate the overall index of growth of the territories and, on its basis, compare the state of the country's economic center and the state of the economic space.

In practical terms, there are two questions. The first is what period should be taken to assess the priority of industries? In response to that, it is proposed to take three years, i.e. if within three years the growth rate of the industry/activity type turned out to be higher than the average for the national economy, then it is recognized as a priority, if lower, then backward, if equal, then current. The second one is which territory to take for evaluation: mega- or macro-region? It is proposed to adopt a macro-region which means to calculate the priority of industries based on macro-regions (i.e., at the level of federal districts).

From the point of view of the criteria put forward, the following sectors are priorities for the national economy of the Russian Federation: agriculture (+ 18.4\%) (Fig. 2) and mining (+ 10.1\%) (Fig. 3). The growth rates for these two sectors exceeded the average annual growth rate for GRP (+ 9.7\%) (Fig. 4).

In accordance with that, high results were achieved in both mega-regions, although the European rate was higher (+ $18.7 \%)$ against the Asian (+ 13.8\%) and therefore, if compared within the industry, the European mega-region is a priority. The other sector - extractive industries - is dominated by the Asian mega-region ( $+12.4 \%$ ) versus $5.8 \%$ in the European mega-region and $+10.1 \%$ with a country-wide growth rate over four years. Thus, from the point of view of a strong criterion - when industry growth rates in the context of mega-regions are compared with GRP growth rates, it turns out that in the Russian Federation only two sectors met the priority criterion: agriculture and mining. In this regard, those mega-macro- and regions in which there is a growing dynamics in these two macro-industries will represent areas of growth. The priority of development in the sectoral plan is the correlation of GRP and the products of industries.

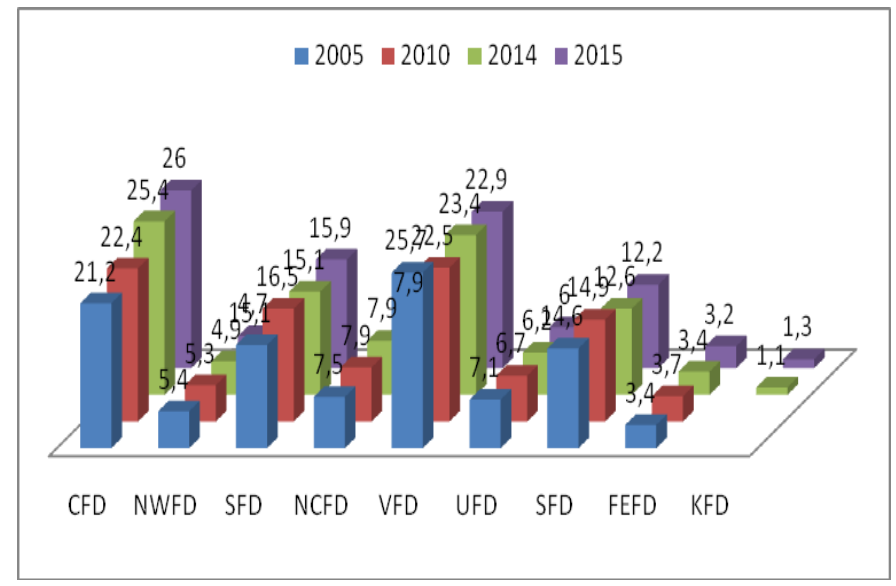

Fig.2. Agriculture produce dynamics by RF federal districts, \%[15]

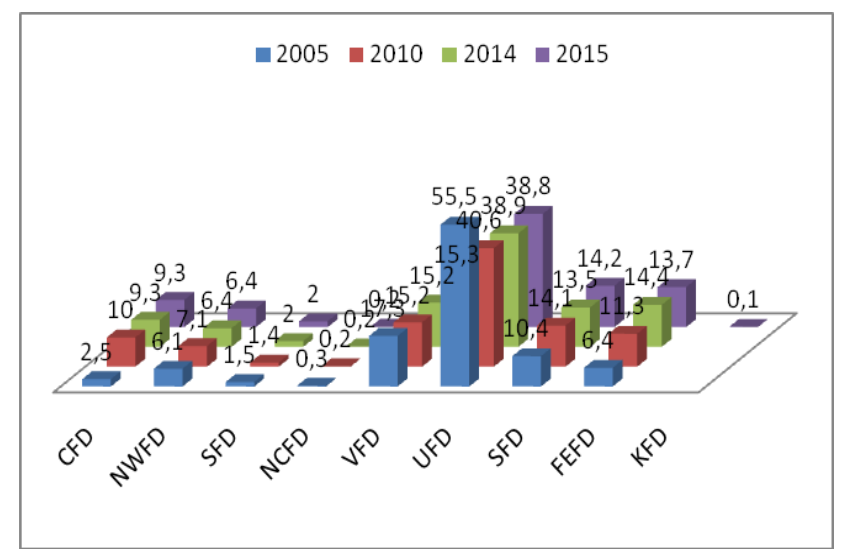

Fig.3. Dynamics of the "Mineral extraction" indicator by RF federal districts, $\%[15]$

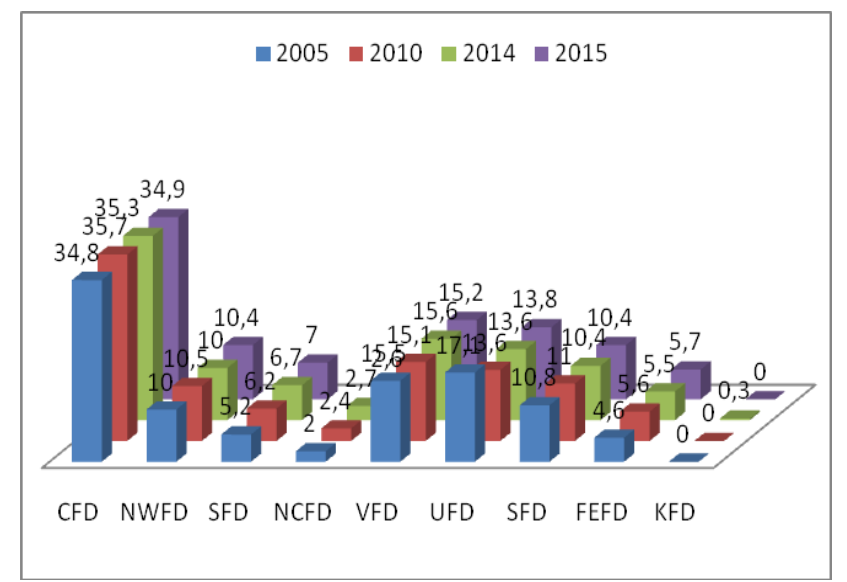

Fig. 4. GRP dynamics by RF federal districts, \%[15]

If we use the criterion of correlation with GRP, it turns out that such industries are: manufacturing industries (the highest correlation coefficient is +0.999 . Although in the European mega-region it is higher than in the Asian mega-region: 0.999 vs. 0.997), retail, catering and paid services (all have a correlation with GRP above 0.995. Moreover, as with the manufacturing industries in the European mega region, the coefficient value is higher than in the Asian one), mineral extraction (+0.984 and, in the Asian mega region the figure is 
higher than in European - 0.988 versus 0.967), agriculture (0.976. The figure in the European mega-region is 0.987, whereas in Asian - 0.961), the production and distribution of electricity, gas and water (0.971. In the European mega-region it is 0.940 and in Asian 0.989), construction (0.935, in the European mega-region - 0.963, in Asian - 0.735), electricity generation (0.807, 0.404 and 0.899 respectively), etc. [14].

\section{DISCUSSION}

The calculated correlation coefficients, in our opinion, can be interpreted, firstly, as a priority in the development of a particular industry in the macroregion, and secondly, the strength of the impulse emanating from the industry in the GRP. We believe that all this is good in terms of assessing the state and prospects for the development of the economic space, the formation of its design, and so on. But it is necessary to determine: firstly, whether the economic center of the country has changed (where it is now, where it was before and where it may be in the future), secondly, whether there was a turn to the east (what is the place of the eastern territories in the new configuration of national economy), thirdly, what did this reversal (if a reversal occurred) bring for the national economy (accelerated its growth development, slowed it down, etc.)? This is a list of questions to be answered. In part, the answer was given above. But the level at which they were considered leaves a kind of dissatisfaction with the answer, and therefore it is necessary to move to the level of the region to answer the question of the country's economic center.

One of the economic space changing architecture features is the displacement of a certain center of mass to the East. The so-called eastern territories - beyond the Urals - represented the following alignment by year: $2005-20.8 \%$, $2010-24.5 \%$, $2014-22.1 \%$. Though, to speak of the mass center as being drawn out in the form of a tail in the east direction is apparently too early and even incorrect, since during this time, the European metropolis grew, respectively, 35.5\%, 39.4\% and $41.0 \%$, that is, firstly, it was more massive (more than 1.5 times), and secondly, its growth rates are higher than in Asia (115.4\% versus $106.1 \%$ ). The mass center forms seven regions of the European mega-region and six regions of the Asian mega-region. The share of the former is approximately 1.2-1.3 times higher than the latter. In addition, if we exclude St. Petersburg from the former list, then their ratio is almost levelled, and in 2010 the regions of the Asian mega-region even exceeded the similar parameter in total of the European mega-region. Another feature is that the growth rates of the Far Eastern specific regions macro-region are among the highest.

\section{CONCLUSIONS}

First, Russia does not need to turn anywhere; in the last century F. Brodel [2], on the basis of a profound study of the main parameters of Russia, determined that already in the XVXVII centuries it was an independent "world-economy" and that means it needs to turn to itself. Current proposals for the development of the Far East and the Asian part of the country in general are often opportunistic in nature and are aimed at subordinating the national economy of Russia to Asian economies: Japan, China, Korea, etc., as well as the USA, thus, making the Russian economy a raw materials addition to these economies. Therefore, it is necessary not to turn to the East, but to introduce a mechanism for the development of the country to the east, but in such a way that it works for Russia, and not for Asia-Pacific countries and states. This means that the Asian part should not be detached from the European part, but, on the contrary, more actively form a single national economic complex. For this, at present there are all objective and subjective factors. First of all, the changed spatial configuration of the national economy of Russia. Secondly, statistically no shift of the economic center to the east is detected. It is true that a center of mass correction is observed. It is connected with the growth of the volume of GRP and some other indicators (the volume of the extractive industry, manufacturing industry and some other productions production), as well as a recovery or approximation to the average Russian level of per capita consumption of goods and services, per capita money income, as well as indicators of social, industrial, transport and other infrastructure, the growth of cash income, wages, pensions and social benefits. Nevertheless, the share of the European part in the main economic indicators remains dominant: variations from 50 to $70 \%$. However, there is reason to foresee in the future the emergence of a new economic center of the country, which, moreover, may be in the East.

\section{Acknowledgment}

The reported study was funded by RFBR, project number 19-010-00289

\section{References}

[1] Aizard W. Location and Space Economy, Technology Press, Wiley. 1956

[2] Braudel F. Space and history. 1994, 406.

[3] Braudel F. Material civilization, economy and capitalism, XV-XVIII centuries. Volume 3. TIME OF PEACE. M .: Progress. 1992.

[4] Budville J. Problems of regional economic planning. Edinburgh. 1966.

[5] Walras L. The beginnings of pure political economy or the theory of social wealth. M .: Izograf. 2000, 448.

[6] [Weber A. On the placement of industry: pure standart theory. M., 1978.

[7] Granberg A.G. Economic Space of Russia: Eternal Problems, Transformational Processes, Search for Strategies. Economic Renaissance of Russia. URL: http://ekvr.narod.ru/revival2.html.

[8] Krugman, P.R., Fujit, M., Venablelson, E. Spatial Economics: Cities, Regions and International Trade. 1999.

[9] Launhard V. Mathematical substantiation of the doctrine of the national economy. 1855.

[10] Lyosh A. Spatial Organization of Economy. M.: Science. 2007, 663.

[11] Leksin V.N., Shvetsov A.N. State and regions: Theory and practice of state regulation of territorial development. M .: Publishing house of the editorial URSS. 2003, 368.

[12] Leontiev, V.V., Economics, Costs - Output. 1966.

[13] Perru F. Economy of the XX century. Per. from French M., 1961.-345c.

[14] Rakhaev B., Shomakhova M., Bizengin B. The Future of Russia: an own, special economic model. Society and Economy. 2012, 9, pp. 3-24.

[15] Regions of Russia. Socio-economic indicators. statistical compilation. M., Rosstat. 2017, 1402.

[16] Smith A. Study on the nature and causes of the wealth of nations. - M.: Publishing House of Social-Econ. lit. 1962, 684. 
[19] Tünen Y. Isolated State in its relation to agriculture and the national economy. M .: Izd. gas. "Econ. a life". 1926, 329.

[17] Sozaeva T.Kh., Eneeva M.N. Problems of territorial organization of socio-economic systems. Terra Economicus. 2012, vol. 10, 3-3, pp. 150152.

[18] Tinbergen J., Bos H. Mathematical models of economic growth. M .: Progress. 1967, 174.
[20] Alexsandr S. Kuznetsov. Russian Professor's meeting. Russian Journal of Physical Education and Sport. 2019, 14(1), pp. 17-22. DOI: 10.14526/2070-4798-2019-14-1-18-24. 